\title{
The Effect of the COVID-19 Pandemic on Smoking Cessation Success
}

\author{
Burcu Kayhan Tetik ${ }^{1}\left[\right.$ ] Işılay Gedik Tekinemre ${ }^{2} \cdot$ Servet Taş $^{3}$
}

Published online: 8 July 2020

(c) Springer Science+Business Media, LLC, part of Springer Nature 2020

\begin{abstract}
The coronavirus pandemic first started in Wuhan, China, in December 2019 and affected the whole world. In our country, new measures to be taken were announced after the first case was seen on March 11, 2020. In this study, patients who admitted to the smoking cessation clinic in 2018 and followed up by phone, regarding smoking cessation status in 2019 were questioned for their smoking cessation status after the coronavirus pandemic in 2020. In this descriptive study, the patients who applied to the smoking cessation outpatient clinic in 2018 were questioned regarding their smoking cessation status after 1 year and after the pandemic. It was investigated whether coronapandemia had an effect on smoking cessation. The data were evaluated by using SPSS 22 software. A value of $\mathrm{p}<0.05$ was considered significant. A total of 357 individuals with a median of Fagerström score of 7.0 were included in the study. Seventy-one (19.9\%) of the subjects used nicotine tape, 268 (75.1\%) used varenicline, and 18 (5.0\%) used both. When the success of those who quit smoking before pandemic and those who quit smoking after pandemic were compared, a statistically significant relationship was found $(\mathrm{p}<0.001)$. In our study, the rate of smoking cessation after 1 year was $23.7 \%$, and the most common side effects were psychiatric complaints, whereas the rate of smoking cessation during the pandemic period was $31.1 \%$. In order to increase the rate of smoking cessation, which is an important public health problem, more counseling should be provided, during the pandemic period.
\end{abstract}

Keywords COVID $19 \cdot$ Smoke $\cdot$ Smoking cessation

\section{Introduction}

The COVID-19 pandemic first started in Wuhan, China, in December 2019 and has affected the whole world. Initially, fear and stress began to increase due to the poorly understood symptoms and sudden deaths. Immediately after the first case was reported in Turkey on March 11, 2020, physical contact between people was reduced to a minimum as per the social distancing regulations introduced. Pertaining to these regulations, schools were closed and remote working systems where possible, were implemented. This new way

Burcu Kayhan Tetik

drburcukayhan@hotmail.com

Işılay Gedik Tekinemre

isilaygedik@ hotmail.com

Servet Taş

servettas@live.com

1 Department of Family Medicine, Inonu University Medical Faculty, Malatya, Turkey

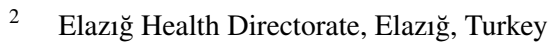

3 Inonu University Faculty of Medicine, Malatya, Turkey of life, with most family members being constantly at home and the significant change in lifestyle, made this period more difficult to manage.

According to most smokers, smoking provides relief and is distressing. During this period, individuals started smoking more cigarettes, in the pursuit of a sense of defense. However, during the pandemic spread, it has been reported that COVID19 mortality rates were higher in those with COPD and in smokers [1]. Some studies have shown that the mortality was 14 times higher in smokers than in normal individuals [2]. Thus, given that smoking is the leading cause of COPD together with the new reports stating that smoking increases the risk of COVID19 has drawn attention once more towards quitting smoking.

In this study, the smoking statuses of patients admitted to the smoking cessation clinic in 2018 and were followed up by phone in 2019 were reinvestigated during the COVID-19 pandemic in 2020 . 


\section{Methods}

In this descriptive study, the records of 357 patients admitted to the Turgut Ozal Medical Center Family Medicine Smoking Cessation Clinic between January 1 and December 31, 2018 and registered on Tobacco Addiction Treatment Monitoring System (TUBATIS) were reviewed retrospectively. Each of the patients had been called by phone, for follow up, in 2019, 1 year after smoking cessation therapy started and questions regarding smoking cessation and drug-related side effects had been asked. Due to the emergence of COVID-19 pandemic, patients were called again and we investigated whether the pandemic had an effect on their smoking cessation statuses.

\section{Statistical Analysis}

The statistical analyses of the data were performed using SPSS 22.0 software. Categorical variables are presented as numbers and percentages (\%), and continuous variables are presented as median interquartile range (25-75 percentile values). The Chi-square test and McNemar test were used to compare categorical variables. The compliance of the parameters to normal distribution was evaluated with the Kolmogorov-Smirnov test. The Mann-Whitney U test was used in independent groups to compare quantitative parameters that did not follow the normal distribution. A value of $\mathrm{p}<0.05$ was considered as statistically significant.

\section{Results}

Three hundred and fifty seven patients, 239 (66.9\%) male and $118(33.1 \%)$ female, were included in this study. The average age of the participants was $39.5 \pm 12.1$ years (range 19 to 73 years). The median Fagerstrom score was 7.0 (6.0-9.0). Seventy-one patients (19.9\%) used a nicotine patch, 268 (75.1\%) used varenicline, and 18 (5.0\%) used both (Table 1).

We found that $79(22.1 \%)$ patients had at least one side effect of the treatment modality used, with psychiatric side effects being the most frequent. Other most common symptoms were nausea, sleep problems, other problems, skin lesions, genitourinary problems and cardiovascular problems, respectively (Fig. 1).

The highest incidence of skin lesions and psychiatric problemswere observed in patients who used nicotine patch and varenicline medication $(\mathrm{p}<0.001, \mathrm{p}=0.007$, respectively) (Table 2).

When the smoking cessation status of the patients was examined 1 year later, we found that 85 (23.8\%) patients
Table 1 Age, gender, the drug used, and Fagerström scores of the participants

\begin{tabular}{lll}
\hline & Sayı & $\%$ \\
\hline Age (median, IQR) & 39.0 & $29.0-49.0$ \\
Gender & & \\
$\quad$ Male & 239 & 66.9 \\
Female & 118 & 33.1 \\
Drug & & \\
Nicotine patch & 71 & 19.9 \\
Varenicline & 268 & 75.1 \\
$\quad$ Nicotine patch + varenicline & 18 & 5.0 \\
Skor (median, IQR) & 7.0 & $6.0-9.0$ \\
\hline
\end{tabular}

$I Q R$ interquartilerange

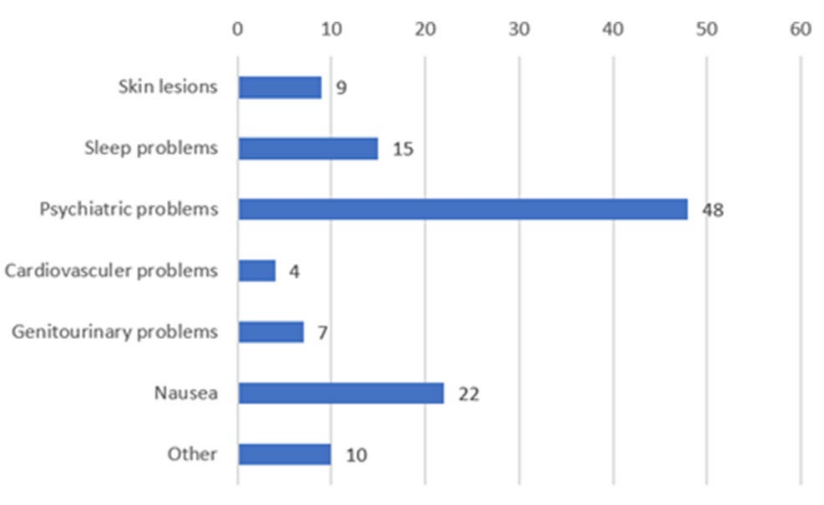

Fig. 1 The most common side effects (n)

quitted smoking, 99 (27.7\%) could not quit, 31 (8.7\%) quitted but started smoking again and 13 (3.6\%) did not use any medication and not quit smoke. One hundred and twenty nine $(36.1 \%)$ of the registered patients could not be reached.

The patients were called by telephone after the pandemic was announced, in order to find out whether the current COVID-19 outbreak had an impact on their smoking status, in May 2020. We found that only 46 (12.8\%) of 357 patients did not start smoking again. We equally found that 165 (46.2\%) of the patients who started smoking again or never quit before, quitted smoking with the fear of the COVID-19 epidemic, whereas 86 (24.1\%) did not quit despite this pandemic. Sixty (16.8\%) of the patients could not be reached.

When the factors affecting the success of smoking cessation were examined; no significant relationship was found between the cessation success and age, gender, medication, exposure to at least one side effect, and nicotine addiction score $(\mathrm{p}>0.05)$.

The comparison between those who quit smoking due to the COVID-19 epidemic and those who did not yielded no statistically significant difference in terms of age, gender and use of medication (Table 3). 
Table 2 Comparison of side effects and the medication used

\begin{tabular}{|c|c|c|c|c|c|c|c|}
\hline & \multicolumn{2}{|c|}{ Nicotine ppatch } & \multicolumn{2}{|c|}{ Varenicline } & \multicolumn{2}{|c|}{$\begin{array}{l}\text { Nicotine patch + vareni- } \\
\text { cline }\end{array}$} & \multirow[t]{2}{*}{$\mathrm{p}^{*}$} \\
\hline & Sayı & $\%$ & Say1 & $\%$ & Sayı & $\%$ & \\
\hline \multicolumn{7}{|c|}{ Skin lesions } & $<0.001$ \\
\hline Yes & 6 & 8.5 & 1 & 0.4 & 2 & 11.1 & \\
\hline No & 65 & 91.5 & 267 & 99.6 & 16 & 88.9 & \\
\hline \multicolumn{7}{|c|}{ Sleep problems } & 0.081 \\
\hline Yes & 0 & 0.0 & 15 & 5.6 & 0 & 0.0 & \\
\hline No & 71 & 100.0 & 253 & 94.4 & 18 & 100.0 & \\
\hline \multicolumn{7}{|c|}{ Psychiatric problems } & 0.007 \\
\hline Yes & 4 & 5.6 & 38 & 14.2 & 6 & 33.3 & \\
\hline No & 67 & 94.4 & 230 & 85.8 & 12 & 66.7 & \\
\hline \multicolumn{7}{|c|}{ Cardiovascular problems } & 1.000 \\
\hline Yes & 1 & 1.4 & 3 & 1.1 & 0 & 0.0 & \\
\hline No & 70 & 98.6 & 265 & 98.9 & 18 & 100.0 & \\
\hline \multicolumn{7}{|c|}{ Genitourinary problems } & 0.419 \\
\hline Yes & 1 & 1.4 & 5 & 1.9 & 1 & 5.6 & \\
\hline No & 70 & 98.6 & 263 & 98.1 & 17 & 94.4 & \\
\hline \multicolumn{7}{|c|}{ Nausea } & 1.000 \\
\hline Yes & 4 & 5.6 & 17 & 6.3 & 1 & 5.6 & \\
\hline No & 67 & 94.4 & 251 & 93.7 & 17 & 94.4 & \\
\hline \multicolumn{7}{|l|}{ Other } & 0.176 \\
\hline Yes & 0 & 0.0 & 9 & 3.4 & 1 & 5.6 & \\
\hline No & 71 & 100.0 & 259 & 96.6 & 17 & 94.4 & \\
\hline
\end{tabular}

*Fisher's exact test

Bold values are statistically significant
Table 3 Evaluation of factors affecting smoking cessation success after coronavirus outbreak

\begin{tabular}{|c|c|c|c|c|c|}
\hline & \multicolumn{2}{|c|}{$\begin{array}{l}\text { Cessation due to } \\
\text { coronavirus }\end{array}$} & \multicolumn{2}{|c|}{$\begin{array}{l}\text { Holding on to } \\
\text { smoking despite } \\
\text { coronavirus }\end{array}$} & \multirow[t]{2}{*}{$\mathrm{p}$} \\
\hline & $\mathrm{n}$ & $\%$ & $\mathrm{n}$ & $\%$ & \\
\hline Age (median, IQR) & 39.0 & $29.0-48.0$ & 38.0 & $27.0-50.0$ & $0.825^{*}$ \\
\hline Gender & & & & & $0.331 * *$ \\
\hline Male & 105 & 63.6 & 60 & 69.8 & \\
\hline Female & 60 & 36.4 & 26 & 30.2 & \\
\hline Medicaiton & & & & & $0.293 * *$ \\
\hline Nicotine patch & 28 & 17.0 & 19 & 22.1 & \\
\hline Champix & 127 & 77.0 & 65 & 75.6 & \\
\hline $\begin{array}{l}\text { Nicotine } \\
\text { patch + Champix }\end{array}$ & 10 & 6.1 & 2 & 2.3 & \\
\hline At least one side effect & & & & & $0.012 * *$ \\
\hline Yes & 44 & 26.7 & 11 & 12.8 & \\
\hline No & 121 & 73.3 & 75 & 87.2 & \\
\hline Score (median, IQR) & 8.0 & $6.0-9.0$ & 7.0 & $5.0-8.0$ & $0.056^{*}$ \\
\hline
\end{tabular}

$I Q R$ interquartilerange

*Mann-Whitney U test

**Chi square test

Bold values are statistically significant
Table 4 The relationship between coronavirus due to smoking cessation and success of smoking cessation

\begin{tabular}{|c|c|c|c|c|c|}
\hline & \multicolumn{2}{|c|}{$\begin{array}{l}\text { Cessation due to } \\
\text { coronavirus }\end{array}$} & \multicolumn{2}{|c|}{$\begin{array}{l}\text { Holding on to } \\
\text { smoking despite } \\
\text { coronavirus }\end{array}$} & \multirow[t]{2}{*}{$\mathrm{p}^{*}$} \\
\hline & Say1 & $\%$ & Say1 & $\%$ & \\
\hline \multicolumn{3}{|c|}{ Success of cessation } & & & $<0.001$ \\
\hline Successful & 38 & 31.1 & 2 & 5.4 & \\
\hline Unsuccessful & 84 & 68.9 & 35 & 94.6 & \\
\hline
\end{tabular}

*McNemar analysis

Bold values are statistically significant

When the success rate of those who quit smoking before pandemic and those who quit smoking after pandemic was compared, a statistically significant difference was found $(p<0.001)$ (Table 4). We found that the COVID-19 outbreak was effective on smoking cessation.

\section{Discussion}

Smoking causes many chronic diseases, decreases the quality of life, and is one of the most preventable causes 
of mortality [3]. In the literature, it has been observed that number of males admitted to the smoking cessation clinics is more than that of females [4-7]. Similarly, in this study, $66.9 \%$ of the patients admitted to the outpatient clinic were male. This finding indicates that the rate of smoking is still much higher in men. The average age of our patients was $39.5 \pm 12.1$ years. The average age in this study is similar to that of other studies [5-9]. This result supports the suggestion that the habit of smoking begins around the age of 17 years and the decision to quit is made around at the age of 40 years, as stated in the literature [10].

In previous studies on smoking cessation, the importance of investigating the smoking status of the patient, sensitizing them about smoking, and encouraging them to quit have been emphasized [11, 12]. In this study, the rate of smoking cessation at the time of follow up after 1 year was $23.8 \%$. When we look at the studies in the literature; Can et al. reported that the 1-year success rate of smoking cessation in the outpatient clinic was $43.4 \%$ and they concluded that this rate was independent of smoking duration, daily number of cigarettes, nicotine addiction level, and educational level [13]. West et al. estimated the rate of smoking cessation at $19 \%$ with the help of intense motivational support and the combination of medical treatment [12]. In the study of D'Angelo et al. 1-year smoking cessation rate was found to be $23.7 \%$ [14]. In our study, unlike other studies, the cessation rates after the COVID-19 pandemic were also examined and statistically higher cessation rates were found. This finding can be explained by the fact that it has been announced that the course of coronavirus infection is more fatal in smokers.

In our study, the Fagerstrom Test for Nicotine Dependence [FTND] was used to determine the level of nicotine addiction. In many studies, it was stated that FTND scores were effective in measuring the level of smoking dependence and evaluating the response to treatment $[15,16]$. In the present study, FTND scores were found to be 7 (range 6-9). In the literature, FTND scores were found to be between 5.4 and 5.7, different from that of our study $[9,17]$. However, in the study conducted by Picakciefe et al., FTND scores were similar to ours [8]. This situation is thought to stem from regional differences.

In the smoking cessation treatment guidelines, it has been stated that the efficiency of nicotine replacement therapies [NRT] and pharmacological treatments in cigarette addiction are quite high $[18,19]$. In our study, in addition to motivational support, the nicotine band was used as nicotine replacement therapy, varenicline active drug as a pharmacological treatment and in some patients a combination therapy including both was used in our outpatient clinic. Since only varenicline could be prescribed to patients free of charge at the time of our study, we did not used bupropion. The nicotine band was used in $19.9 \%$ of our patients, varenicline was used in $75.1 \%$, and a combination of both was used in 5\%. The choice of treatment for the patients was determined by the clinical conditions and addiction levels of the patients.

In this study, at least one side effect was observed in $22.1 \%$ of the patients with the most common being psychiatric problems. This could be because most of our patients used varenicline, which has such side effects. It has been observed that the frequency of psychiatric problems were higher in patients using a combination therapy of nicotine band and varenicline. Patients treated with a combination therapy of NRT and varenicline have higher dependency levels and accordingly, feel more nicotine deficiency. In the study conducted by Demir et al., it was reported that stress nervousness, and difficulties of concentration were observed most frequently due to nicotine deficiency and these complaints were more common in the group without NRT [20]. In the present study, the second most common side effect, nausea, was most commonly seen in those using varenicline, while still being present in those using NRT and in those using a combination therapy of both. Nausea is known to be among the side effects of varenicline and NRT.

The COVID-19 pandemic is an urgent public health problem affecting the whole world. The coronavirus, which especially affects the respiratory tract, enters the body through the upper respiratory tract mucosa via the nasal and oral routes [21]. Smoking causes chronic inflammation in the upper respiratory tract mucosa, collects cytokines into this area, disrupts mucociliary activity, and causes overproduction of mucus [22]. It has been reported that the current COVID-19 disease is more fatal in smokers. In cigarette smoking-related studies during this period, smoking status was found to be the only associated factor in the logistic regression analysis regarding COVID-19 pneumonia [23]. Lippi et al. found no relation was found between smoking and COVID-19 pneumonia [24]. The reason for these contradictory results may be due to the fact that the studies conducted were carried out in a short period of time during the pandemic period and the sample size was small. The continuous hand to mouth contact during smoking activity is another important factor that increases the risk of contamination. Given these situations, smoking cessation has gained substantial importance in this period.

In the current study, the rate of smoking cessation was $23.8 \%$ at the end of first year, while the rate of those who quit smoking was $31.1 \%$ during the COVID-19 pandemic. Klemperer et al. reported that $22.9 \%$ of their subjects reduced smoking, $21.2 \%$ reduced electronic cigarette use, and $16.2 \%$ quit smoking during the COVID-19 pandemic, with the fear of being harmed during this period [25]. On the other hand, in the study of Leventhal Adam et al., it was found that $30 \%$ of the patients increased the amount of cigarettes and 15\% became less motivated for cessation; they attributed this situation to negative affection [26]. According to our findings, 
we suggest that the motivation was strengthened by the feeling of fear after the COVID-19 pandemic overwhelmed the negative affection. We suggest that the success of cessation can be increased by informing the patients on the increased risks with the COVID-19 pandemic during the meetings at the smoking cessation interviews.

\section{Conclusion}

In our study, the rate of smoking cessation was $23.7 \%$ and the most common adverse effect was psychiatric complaints in a 1-year follow up. Smoking cessation rates were found to increase up to $31.1 \%$ during the pandemic. We believe that smoking cessation rates have increased due to the common fear experienced during the pandemic. Considering that individuals who smoke during this period may be affected by the COVID-19 pandemic more and in worse ways, it is necessary to conduct cessation studies more decisively and the interviews should include informing about the combined risks with the COVID-19 pandemic.

\section{References}

1. Turan, O., \& Mirici, A. Kronik Obstrüktif Akciğger hastalı̆̆ 1 ve COVID-19 Türkiye Solunum Araştırma Derneği.

2. Liu, W., Tao, Z. W., Lei, W., Ming-Li, Y., Kui, L., Ling, Z., et al. (2020). Analysis of factors associated with disease outcomes in hospitalized patients with, 2019 novel coronavirus disease. Chinese Medical Journal. https://doi.org/10.1097/CM9.0000000000 000775.

3. Simon, A. J., Carmody, T. P., Hudes, H. S., et al. (2003). Intensive smoking cessation counselling versus minimal counselling among hospitalized smokers treated with transdermal nicotine replacement: A randomized trial. The American Journal of Medicine, $114,555-562$.

4. Argüder, E., Karalezli, A., Hezer, H., \& ve ark. (2013). Sigara bırakma başarısını etkileyen faktörler. Turk Toraks Derg, 14, 81-87 (In Turkish).

5. Can, G., Oztuna, F., \& Topbaş, M. (2007). Complaints related to smoking cessation. Tuberk Toraks, 55, 364-369. (In Turkish).

6. Sağlam, L. (2012). Investigation of the results of a smoking cessation clinic and the factors associated with success. Turkish Journal of Medical Sciences, 42, 515-522.

7. Mutlu, P., Yıldırım, B. B., \& Açıkmeşe, B. (2015). Results taken from a smoking cessation clinic at a second-level state hospital. İstanbul Medicine Journal, 16, 145-148.

8. Pıçakçıefe, M., Akkaya, V., Erbaş, E., \& Doğu, B. (2019). Muğla'da 2015-2016 yılları arasında sigara bırakma polikliniğine yapılan başvuruların değerlendirilmesi. Evaluation, 33, 38.

9. Abakay, Ö., Abakay, A., Tanrıkulu, A. Ç., et al. (2014). The outcome of patients that admitted to out patients of smoking cessation. Journal of Chest Disease and Critical Care, 1, 7-10.

10. Şahbaz, S., Kılınç, O., Günay, T., \& Ceylan, E. (2007). The effects of smoking properties and demographic properties on the results of smoking cessation therapy. Toraks Dergisi, 8(2), 110-114.
11. US PublicHealth Service Report. (2000). A clinical practice guideline for treating tobacco use and dependence. JAMA, 283, 3244-3254.

12. West, R., McNeill, A., \& Raw, M. (2000). Smoking cessation guidelines for health professionals: An update Health Education Authority. Thorax, 55(12), 987-999.

13. Can, G., Oztuna, F., \& Ozlu, T. (2004). Karadeniz Teknik Üniversitesi Tıp Fakültesi sigara bırakma polikliniği sonuçlarının değerlendirilmesi. TuberkToraks, 52(1), 63-74.

14. D’Angelo, M. E., Reid, R. D., Brown, K. S., et al. (2001). Gender differences in predictors for longterm smoking cessation following physician advice and nicotinere placement therapy. Canadian Journal of Public Health, 92(6), 418-422.

15. Örsel, O., Örsel, S., Alpar, S., \& ve ark. (2005). Sigara birakmada nikotin bağımlılık düzeylerinin tedavi sonuçlarına etkisi. Solunum Hastalıklart, 16, 112-118.

16. Kozlowski, L. T., Porter, C. Q., Orleans, C. T., Pope, M. A., \& Heatherton, T. (1994). Predicting smoking cessation with selfreported measures of nicotine dependence: FTQ, FTND, and HSI. Drug and Alcohol Dependence, 34, 211-216.

17. Salepci, B. M., Havan, A., Fidan, A., Kıral, N., \& Saraç, G. (2013). Sigara birakma polikliniğinin KOAH ve küçük hava yolu hastalı̆̆ının erken tespitine katkısı. Solunum, 15, 100-104.

18. Tobacco, T. C. P. G. T. (2008). A clinical practice guideline for treating tobacco use and dependence: 2008 update: A US public health service report. American Journal of Preventive Medicine, 35(2), 158-176.

19. West, R., McNeill, A., \& Raw, M. (2000). Smoking cessation guidelines for health professionals: An update. Thorax, 55, 987-999.

20. Demir, T., Tutluoğlu, B., Koç, N., \& Bilgin, L. (2004). Sigara bırakma polikliniğimizin bir yıllık izlem sonuçları. Tüberküloz ve Toraks Dergisi, 52(1), 63-68.

21. Berlin, I., Thomas, D., Le Fauo, A. L., \& Cornuz, J. (2020). Covid 19 and smoking. Nicotine Tobacco and Research. https://doi. org/10.1093/ntr/ntaa059.

22. Strzelak, A., Ratajczak, A., Adamiec, A., \& Feleszko, W. (2018). Tobacco smoke induces and alters immune responses in the lung triggering inflammation, allergy, asthma and other lung diseases: A mechanistic review. International Journal of Environmental Research and Public Health., 15(5), 1033.

23. Zhang, J. J., Dong, X., Cao, Y. Y., et al. (2020). Clinical characteristics of 140 patients infected with SARS-CoV-2 in Wuhan, China. Allergy. https://doi.org/10.1111/all.14238.

24. Lippi, G., \& Henry, B. M. (2020). Active smoking is not associated with severity of coronavirus disease 2019 (COVID-19). European Journal of Internal Medicine., S0953-6205(20), 30110-30112. https://doi.org/10.1016/j.ejim.2020.03.014.

25. Klemperer, E. M., West, B. A., Peasley-Miklus, C., \& Villanti, A. C. (2020). Change in tobacco and electronic cigarette use and motivation to quit in response to COVID-19. Nicotine \& Tobacco Research, 1-2.

26. Leventhal, A. M., Greenberg, J. B., Trujillo, M. A., et al. (2013). Positiveand negative affect as predictors of urgetosmoke: Temporal factors and mediational pathways. Psychology of Addictive Behaviors., 27(1), 262-267.

Publisher's Note Springer Nature remains neutral with regard to jurisdictional claims in published maps and institutional affiliations. 